\title{
A high-frequency time series at Ocean Weather Ship Station M (Norwegian Sea): population dynamics of Calanus finmarchicus
}

\author{
Hans-Jürgen Hirche*, Thomas Brey, Barbara Niehoff
}

Alfred Wegener Institute for Polar and Marine Research, Columbusstr. 1, 27568 Bremerhaven, Germany

\begin{abstract}
Between the end of March and mid-June 1997, net samples in the upper $100 \mathrm{~m}$ were taken almost daily on Weathership M (Norwegian Sea) to determine the abundance and stage composition of Calanus finmarchicus. Biomass showed high day-to-day variability with several peaks, ranging from 0.05 to $6.3 \mathrm{~g} \mathrm{C} \mathrm{m}^{-2}$, with an average of $0.84 \mathrm{~g} \mathrm{C} \mathrm{m}^{-2}$. Consequently, stage abundances were also highly variable, but stage composition was consistent. Although population egg production was almost constant throughout the study period, a clear cohort was formed. During the pre-bloom period, nauplii and Copepodite Stage I (CI) were frequently abundant, but further stage development proceeded only during the short bloom. At the end of the bloom, no young nauplii continued to grow, but older stages did. Some specimens had reached CV at the end of the investigation period. The extended seasonal presence of some stages made estimates of stage duration and production difficult. Three different numerical methods were applied to estimate productivity and production. All methods resulted in similar estimates of productivity, 0.031 to $0.055 \mathrm{~d}^{-1}$, corresponding to a production of 30 to $56 \mathrm{mg} \mathrm{C} \mathrm{m}^{-2} \mathrm{~d}^{-1}$. These rates are considerably lower than optimum rates measured in the laboratory, suggesting strong food limitation of growth during most of the observation period.
\end{abstract}

KEY WORDS: Population dynamics $\cdot$ Calanus finmarchicus $\cdot$ Norwegian Sea $\cdot$ Food limitation Resale or republication not permitted without written consent of the publisher

\section{INTRODUCTION}

The copepod Calanus finmarchicus is a key species in the pelagic system of the North Atlantic, coupling primary production and zooplanktivorous fish (Runge 1988). A strong interannual variability in its abundance has been described recently by Planque \& Fromentin (1996), and Fromentin \& Planque (1996) have demonstrated correspondences between its oceanic abundance and the North Atlantic Oscillation (NAO). The oceanic stocks are of vital importance for the shelf seas (Steele 1998). Thus, Marshall \& Orr (1955) recognized the dependence of the abundance of $C$. finmarchicus in the North Sea on immigration from the North Atlantic. Similar immigration takes place on the Norwegian shelf (e.g. Slagstad \& Tande 1996) and

*E-mail: hhirche@awi-bremerhaven.de
Georges Bank (Miller et al. 1991), where C. finmarchicus supports local fish stocks.

Despite considerable efforts to understand the life cycle and production of this species, little is known about the population dynamics and the factors controlling it in the open ocean. This is, however, a prerequisite to understanding the effect of climatological changes on the production of this species and the system it inhabits. So far, time series of abundance data, with reasonable temporal resolution, from the open North Atlantic are only available from Ocean Weather Ship Stations 'Mike' (Østvedt 1955) and 'India' (Williams 1988, Irigoien 2000). In addition, the Continuous Plankton Recorder dataset has been analyzed for seasonal abundance (e.g. Colebrook 1982). Most studies have concentrated on fjords (Tande 1982, Aksnes \& Magnesen 1983, Diel \& Tande 1992), coastal areas and shallow seas (Fransz \& van Arkel 1980, Williams \& Lindley 1980, Fransz \& Diel 1985, Diel \& Klein Breteler 
1986, Durbin et al. 1995, Gaard 1996, Gislason \& Astthorson 1996).

From these studies and laboratory observations a concept evolved describing Calanus finmarchicus as a conservative spawner, which spawns only after serving its basic metabolic needs (Runge 1985). The need for high food densities in order to start producing eggs

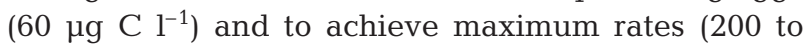
$300 \mu \mathrm{g} \mathrm{C}^{-1}$, Runge 1985) seemed to imply a close link between production of the spring generation and the spring bloom (Marshall \& Orr 1955, Cushing 1959, Diel \& Tande 1992, Plourde \& Runge 1993). This view was supported by the high threshold concentration for ingestion that was measured by Gamble (1978) and Daro (1980) and was later applied in models (Carlotti \& Radach 1996, Carlotti \& Hirche 1997).

In contrast to this concept, the presence of spawning females and young stages of Calanus finmarchicus before the spring bloom indicated the onset of reproduction before the phytoplankton bloom (Østvedt 1955, Melle \& Skjoldal 1987). The importance of pre-bloom spawning at Ocean Weather Ship Station 'Mike' (Station M) in the Norwegian Sea $\left(66^{\circ} \mathrm{N}, 2^{\circ} \mathrm{E}\right)$ was recently reported by Niehoff et al. (1999). Although egg production was strongly food-limited, approximately half of the egg production of the population was deposited before the onset of the bloom at the beginning of May. The question arose whether the offspring were able to develop and whether growth, as well as egg production, was food-limited. Based on laboratory experiments with small calanoids (Uye 1982, Kiørbœ et al. 1985, Fryd et al. 1991), it has been suggested that somatic production of young stages would equal specific egg production of the female also in C. finmarchicus (Laabir et al. 1995, Hirche 1996). In this case, egg production could be used as a measure of secondary production.

This study describes the development of the spring generation of Calanus finmarchicus at Station $\mathrm{M}$ in relation to food concentration. The high sampling frequency allowed us to study the dynamic relationship between phytoplankton development and the production of $C$. finmarchicus. We applied and compared different methods to estimate production based on population structure and egg production. Recent information from laboratory rearings (Campbell et al. in press) and the equations from Huntley \& Lopez (1992) have also been compared. Furthermore, we used the 1948/1949 dataset from the same location (Østvedt 1955) for interannual comparison.

\section{MATERIALS AND METHODS}

Sampling. The time series at Station M was obtained from 22 March to 9 June 1997. Details on the ship's drift and the hydrography, phytoplankton concentrations and reproductive biology at the site are published in Irigoien et al. (1998) and Niehoff et al. (1999). During the investigation period of $80 \mathrm{~d}$, vertical hauls with a WP2 net (mesh size $50 \mu \mathrm{m}$ ) from the upper $100 \mathrm{~m}$ were taken at $0.3 \mathrm{~m} \mathrm{~s}^{-1}$ on 65 days at around 10:00 h. The hauls were fixed in $4 \%$ formalin buffered with hexamethylentetramin, for determination of abundance. A sampling efficiency of $100 \%$ was assumed as, due to the low phytoplankton concentrations, no clogging was expected or observed.

Counting and species identification. The 4 species Calanus finmarchicus, C. helgolandicus, C. glacialis and $C$. hyperboreus are all found at this site (A. Bucklin et al. unpubl.). During the present study, prosome length from the tip of the cephalosome to the distal lateral end of the last thoracic segment was measured from $50 \mathrm{CV}$ and adult females per sample using a video image digitizing system with a resolution of $25 \mu \mathrm{m}$. According to body size and curvature of the fifth swimming leg there were no C. helgolandicus or C. glacialis of these stages in the samples. Therefore no nauplii or young copepodites of these species were expected either. The co-occurring C. hyperboreus are easily distinguished by their much larger size (Hirche et al. 1994). Eggs were identified by their size. Nauplii were sorted according to size and morphological characteristics; for separation from Pseudocalanus spp. and $C$. hyperboreus the characters described by Østvedt (1955) were used. NI and NII and NIV to NVI were pooled. All adults and CV were counted; for the younger stages the sample was split down to $1 / 128$ if necessary. At least 100 specimens of each stage were counted when possible.

Dry weight and carbon content. For the analysis of dry weight, every week, groups of 10 adult females and $10 \mathrm{CV}$, respectively, were sorted alive on preweighed aluminum dishes from WP2 samples, rinsed briefly in distilled water and frozen $\left(-25^{\circ} \mathrm{C}\right)$. Later they were dried at $60^{\circ} \mathrm{C}$ for $48 \mathrm{~h}$ and measured on a Sartorius microbalance. For conversion to carbon content a factor of 0.5 was applied to measurements of dry weight.

Productivity calculation. Somatic production and productivity were estimated by 3 different methods: (1) the increment summation method, (2) a mortality model, and (3) from egg production rates.

Increment summation method: Somatic production and productivity were computed with 2 different approaches according to Rigler \& Downing (1984) and Crisp (1984). Method 1 computes production from stage to stage, either by (Method 1A) daily increment in biomass:

$$
P_{i, i+1}=\left(M_{i+1}-M_{i}\right) \times\left(X_{i} / D_{i}+X_{i+1} / D_{i+1}\right) / 2
$$


Table 1. Production calculation by increment summation. Method 1A: increment in biomass. Method 1B: loss of biomass. Method 2: production within stage 1. Minimum and maximum body mass computed by: $M_{2, \min }=\left(M_{1}+M_{2}\right) / 2 ; M_{2, \max }=M_{3, \min }$

\begin{tabular}{|c|c|c|c|c|c|c|c|c|c|}
\hline \multirow[t]{2}{*}{ Stage } & \multirow{2}{*}{$\begin{array}{c}\text { Mean } \\
\text { abundance } \\
X\left(\mathrm{~m}^{-2}\right)\end{array}$} & \multirow{2}{*}{$\begin{array}{l}\text { Duration } D \\
\quad \text { (days) }\end{array}$} & \multirow[t]{2}{*}{$\mathrm{X} / \mathrm{D}$} & \multicolumn{3}{|c|}{ Body mass ( $\mu \mathrm{g} C)$} & \multicolumn{3}{|c|}{ Production (mg C m$\left.{ }^{-2} \mathrm{~d}^{-1}\right)$} \\
\hline & & & & Mean & Minimum & Maximum & Method 1A & Method 1B & Method 2 \\
\hline Eggs & 47744 & $2^{\mathrm{a}}$ & 23872 & 0.23 & 0.00 & 0.23 & & & $(5.49)$ \\
\hline NI/NII & 3806 & $5^{\mathrm{a}}$ & 761 & $0.19^{\mathrm{b}}$ & $0.19^{b}$ & 0.25 & -0.49 & 4.85 & 0.04 \\
\hline NIII & 10753 & 13 & 827 & 0.30 & 0.25 & 0.50 & 0.09 & -0.02 & 0.21 \\
\hline NIV/NVI & I 15585 & 9 & 1732 & 0.70 & 0.50 & 1.55 & 0.51 & -0.45 & 1.82 \\
\hline $\mathrm{CI}$ & 7170 & 6 & 1195 & 2.40 & 1.55 & 4.00 & 2.49 & 0.83 & 2.93 \\
\hline $\mathrm{CII}$ & 6241 & 7 & 892 & 5.60 & 4.00 & 8.45 & 3.34 & 1.21 & 3.97 \\
\hline CIII & 6645 & 9 & 738 & 11.30 & 8.45 & 20.15 & 4.65 & 1.29 & 8.64 \\
\hline CIV & 6627 & 12 & 552 & 29.00 & 20.15 & 55.00 & 11.42 & 3.75 & 22.01 \\
\hline $\mathrm{CV}$ & 2939 & $12^{\mathrm{a}}$ & 245 & $91.00^{c}$ & 60.00 & 101.90 & 24.71 & 18.44 & 10.26 \\
\hline \multirow[t]{2}{*}{ Adults } & 3632 & $24^{\mathrm{a}}$ & 151 & $112.80^{\mathrm{c}}$ & 101.90 & $144.25^{\mathrm{c}}$ & 4.32 & 9.54 & 6.14 \\
\hline & & & & & & $\begin{array}{l}\sum \text { pridual biomass }{ }^{\mathrm{d}} \\
\text { Mean biomastion } \\
P / B \text { ratio }\left(\mathrm{d}^{-1}\right)\end{array}$ & $\begin{array}{c}- \\
51.03 \\
1022.42 \\
0.050\end{array}$ & $\begin{array}{c}17.07 \\
56.52 \\
1022.42 \\
0.055\end{array}$ & $\begin{array}{c}- \\
56.28 \\
1022.42 \\
0.055\end{array}$ \\
\hline
\end{tabular}

or by (Method 1B) daily loss of biomass:

$$
P_{i, i+1}=\left(X_{i} / D_{i}-X_{i+1} / D_{i+1}\right) \times\left(M_{i}+M_{i+1}\right) / 2
$$

If the population is in a steady state, both approaches will result in the same population production figure.

Method 2 computes daily production $P$ within each stage:

$$
P_{i}=\left(M_{i, \max }-M_{i, \min }\right) X_{i} / D_{i}
$$

where $X_{i}, M_{i}, M_{i, \max }$ and $M_{i, \min }$ are average abundance, mean, maximum and minimum body mass in Stage $i$, respectively, and $D_{i}$ is the duration of the stage in days. Stage duration was inferred from the development of stages over the sampling period (NIII, NIV/NVI, CI to CIV) using data from the literature or the steepest-increase method (Table 1): (1) The $3 \mathrm{~d}$ moving average (MA3) of the abundance of each stage was computed. (2) All MA3s were converted into a percentage of the sum of all stages at the corresponding day, and a $3 \mathrm{~d}$ weighed average (WA3) was computed for each stage. (3) The steepest increase in the WA3 of a particular stage was defined as the start of this stage's lifespan and as the end of the previous stage's lifespan.

For comparison purposes, stage duration was also calculated using the median development time method (Landry 1983). Abundances were smoothed with a 4point running mean filter, and proportions of individuals who had completed a given molt were calculated (see Fig. 4a). A linear regression was fit only to the linear portions of these curves (Fig. 4b). Stage duration was then depicted as the distance between successive stages at $50 \%$ frequency.
Mean biomass per day was computed from average abundance and mean body mass per stage during the investigation period. Body mass for the developmental stages was taken from the literature (Table 2) or from dry weight measurements converted to carbon (Table 3).

Mortality model: Mortality rate $Z$ was estimated by the single negative exponential mortality model,

$$
N_{t}=N_{\mathrm{o}} \mathrm{e}^{-Z t}<=>\ln \left(N_{t}\right)=\ln \left(N_{\mathrm{o}}\right)-Z t
$$

where $N$ is abundance and $t$ is age, i.e. by a linear regression of the ln-transformed abundance data

Table 2. Carbon content $(\mu \mathrm{g})$ of developmental stages of Calanus finmarchicus used in calculations of biomass and

\begin{tabular}{|c|c|c|}
\hline Eggs & 0.23 & Ohman \& Runge (1994) \\
\hline NI/NNII & 0.19 & Estimated \\
\hline NIII & $0.30^{\mathrm{b}}$ & Carlotti et al. (1993) \\
\hline NIV/NVI & $0.70^{\mathrm{b}}$ & Carlotti et al. (1993) \\
\hline $\mathrm{CI}$ & 2.4 & Hirche (unpubl.) \\
\hline CII & 5.6 & Hirche (unpubl.) \\
\hline CIII & 11.3 & Hirche (unpubl.) \\
\hline CIV & 29 & Hirche (unpubl.) \\
\hline $\mathrm{CV}$ & $65-137^{a}$ & Present study \\
\hline $\mathrm{AF}$ & $92-130^{a}$ & Present study \\
\hline $\mathrm{AM}$ & $90-153^{a}$ & Present study \\
\hline \multicolumn{3}{|c|}{$\begin{array}{l}\text { a Calculated from data presented in Table } 3 \text {, assuming } C= \\
50 \% \text { dry weight } \\
{ }^{b} \text { Mean of all available data in Carlotti et al. (1993, their } \\
\text { Fig. 1), assuming } C=50 \% \text { dry weight }\end{array}$} \\
\hline
\end{tabular}
production. N: nauplius; C: copepodite; AF: adult females; AM: adult males 
$\left(X_{i} / D_{i}\right)$ versus the cumulative stage duration $\left(D_{i}\right)$. In steady state populations, mortality rate $Z$ approximates the production-to-biomass ratio (Allen 1971, Brey 1999) and hence is an additional proxy for somatic productivity.

Egg production rates: Specific egg production rate (SEPR) has been suggested as a measure of population growth for Calanus spp. (Laabir et al. 1995, Hirche 1996), assuming the SEPR to be equivalent to somatic growth. Daily SEPR was calculated using mean daily egg production at Station M from Niehoff et al. (1999), an egg weight of $0.23 \mu \mathrm{g} \mathrm{C}$ (Ohman \& Runge 1994) and female carbon content converted from weekly dry weight measurements (Table 3 ). Daily secondary production of the population was computed by multiplying daily SEPR with population biomass.

Other growth rates: For comparison, growth rate was calculated according to Huntley \& Lopez (1992) from the relationship:

$$
g=0.0445 \mathrm{e}^{0.111 T}
$$

where $T$ is temperature. Growth rate was also calculated by Campbell et al. (in press) for developmental times obtained under optimum food conditions. Developmental time $(D)$ from egg to CVI was calculated from their Belehradek equation:

$$
D=\mathrm{a}(T+9.11)^{-2.05}
$$

Growth rate was then calculated from $D$ using the equation from Huntley \& Lopez (1992):

$$
g=0.025+(4.327 / D)
$$

\section{RESULTS}

\section{Hydrography and phytoplankton}

Environmental conditions are only briefly described here; details are presented in Irigoien et al. (1998) and Meyer-Harms et al. (1999). Station M is situated on the slope of the Norwegian Shelf in the North Atlantic Current. In the study area, the surface water is of Atlantic origin (Hopkins 1991). According to temperature and salinity measurements (Irigoien et al. 1998), the Atlantic layer mostly extends to 300-400 m depth and does not rise above $150 \mathrm{~m}$ depth. Samples for the present study were therefore taken in Atlantic water throughout the investigation period. Intermediate water of Atlantic and Polar origin (temperature $<3^{\circ} \mathrm{C}$, salinity $<35 \mathrm{psu}$ ) underlies the Atlantic water in depths between 150 and $700 \mathrm{~m}$; the deep water in this region is formed by Polar water (see Hopkins 1991).

Three periods of phytoplankton development were distinguished at Station M (Irigoien et al. 1998, Niehoff
Table 3. Dry weights $(\mu \mathrm{g})$ of $\mathrm{CV}$, adult females (AF), and males (AM) of Calanus finmarchicus from Weathership M. Averages of 2 parallel samples

\begin{tabular}{|cccc|}
\hline \multicolumn{1}{l}{ Date } & CV & AF & AM \\
\hline 23 Mar & No data & 235 & - \\
30 Mar & 180 & 210 & 305 \\
$6 \mathrm{Apr}$ & 185 & 275 & 245 \\
$13 \mathrm{Apr}$ & 175 & 210 & 220 \\
$24 \mathrm{Apr}$ & 130 & 185 & 180 \\
1 May & 130 & 200 & 265 \\
8 May & 145 & 190 & 230 \\
12 May & 165 & 215 & 210 \\
17 May & 215 & 235 & 185 \\
27 May & 275 & 260 & - \\
2 Jun & 200 & 235 & - \\
8 Jun & 205 & 220 & - \\
\hline
\end{tabular}

et al. 1999). During the pre-bloom (22 March to 10 May), the upper $200 \mathrm{~m}$ were well mixed, with temperatures between 5 and $6^{\circ} \mathrm{C}$. The chlorophyll a concentration was very low at $<0.5 \mu \mathrm{g} \mathrm{l}^{-1}\left(<40 \mathrm{mg} \mathrm{m}^{-2}\right.$ integrated total chlorophyll a for the upper $100 \mathrm{~m})$. During this period, small algae $(<5 \mu \mathrm{m})$, e.g. green algae (approx. $40 \%$ ), haptophytes (approx. $30 \%$ ) and cryptophytes (approx. 25\%), were dominating the phytoplankton community (Irigoien et al. 1998). The warming of the surface water led to stratification at 30 to $50 \mathrm{~m}$ depth, and subsequently (11 to 29 May) a phytoplankton bloom developed, with a maximum chlorophyll a concentration of $3 \mu \mathrm{g} \mathrm{l}^{-1}\left(133 \mathrm{mg} \mathrm{m}^{-2}\right.$ integrated total chlorophyll $a$ for the upper $100 \mathrm{~m}$ ). The cell size distribution of the algae shifted to larger cells; dominant taxa during the bloom were diatoms (approx. $30 \%$ ), cryptophytes (approx. 30\%) and dinoflagellates (approx. 15\%). By the end of May, the chlorophyll a concentration decreased and did not exceed $1.5 \mathrm{\mu g} \mathrm{l}^{-1}$ (60 $\mathrm{mg} \mathrm{m}^{-2}$ integrated total chlorophyll a for the upper $100 \mathrm{~m}$ ) during the post-bloom (30 May to 9 June). During this period, haptophytes and cryptophytes were dominant again, shifting the cell size distribution back to smaller cells.

\section{Biomass and abundance}

During the period of investigation, the seasonal ontogenetic migration was almost completed (W. Melle et al. unpubl.) and most of the Calanus finmarchicus population was found in the upper strata during the whole investigation period. Only females were abundant below $100 \mathrm{~m}$, in varying numbers during part of the study period (Niehoff et al. 1999), but they were not considered here. Biomass of the C. finmarchicus population in the upper $100 \mathrm{~m}$ is presented in Fig. $1 \mathrm{~b}$. 

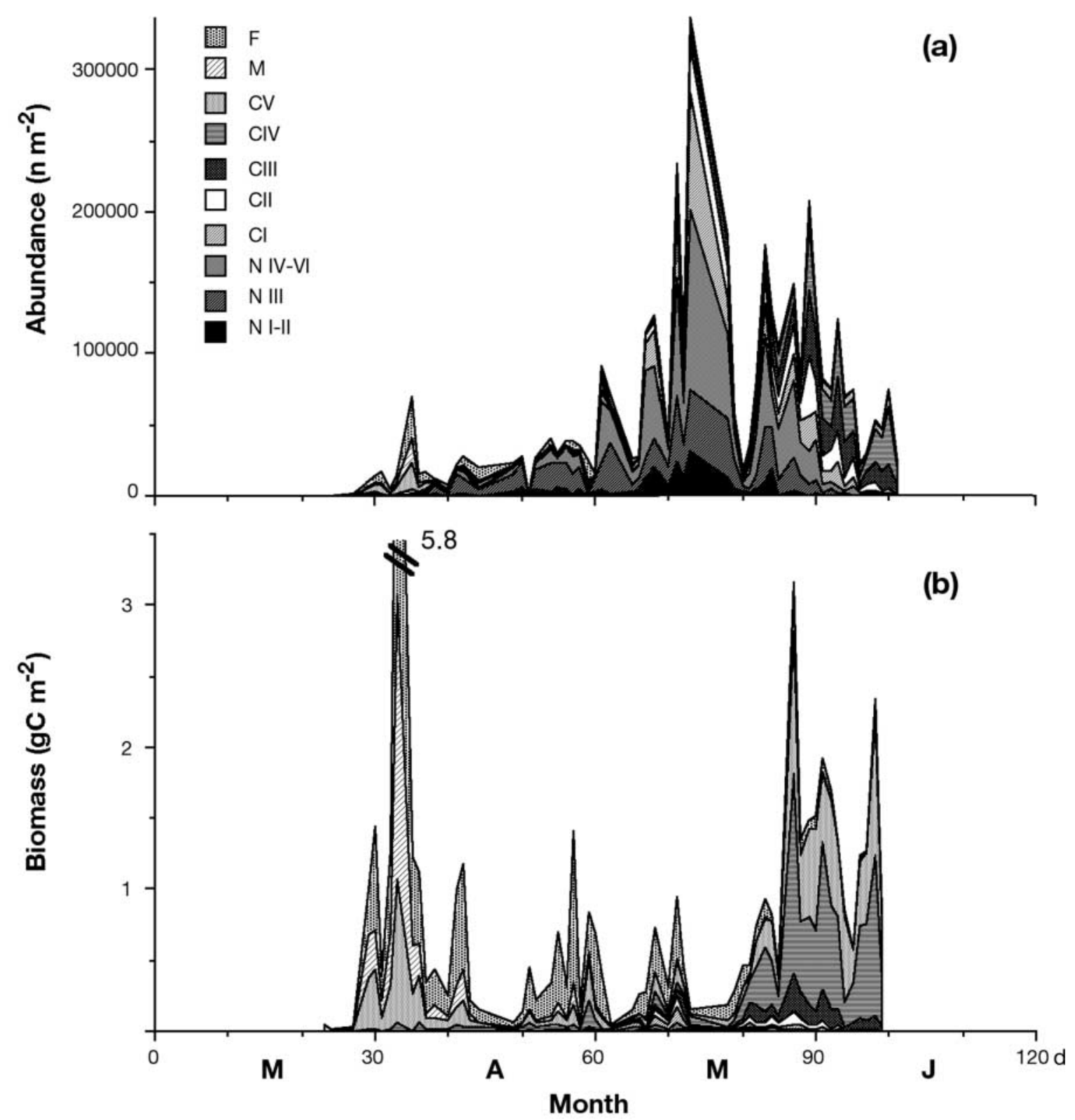

Fig. 1. Abundance (a) and biomass (b) of Calanus finmarchicus at Station M between March and June 1997

Details on the vertical distribution of adult females were described by Niehoff et al. (1999). Abundance was highly variable (Fig. 1a), ranging from 950 to 335000 ind. $\mathrm{m}^{-2}$, including all stages except eggs. The outstanding peak in abundance of $\mathrm{CV}$, adult males and adult females on 4 April (Fig. 2) co-occurred with an intrusion of colder (Irigoien et al. 1998) and saltier (Klenke 1998) water recorded mostly below $200 \mathrm{~m}$ and lasted only $1 \mathrm{~d}$. Highest numbers were recorded in mid-May during an outburst of naupliar development. Weekly biomass of adult females, males and CV is presented in Table 3. Biomass showed considerable variability, with several peaks, ranging from 0.05 to $6.3 \mathrm{~g} \mathrm{C} \mathrm{m}^{-2}$ (Fig. 1b), and an average of $0.84 \mathrm{~g} \mathrm{C} \mathrm{m}^{-2}$. As expected, biomass was proportional to the presence of older stages.

Despite high variability of total abundance, stage composition was consistent (Fig. 2). The population stage distribution shifted through time towards older stages, suggesting an actively developing cohort of the spring generation $\left(\mathrm{G}_{1}\right)$ during the study period. Distinct cohort development is clearly apparent in the cumulative portion of all stages (Fig. 3). Nauplii were present from the beginning of the investigation but at 


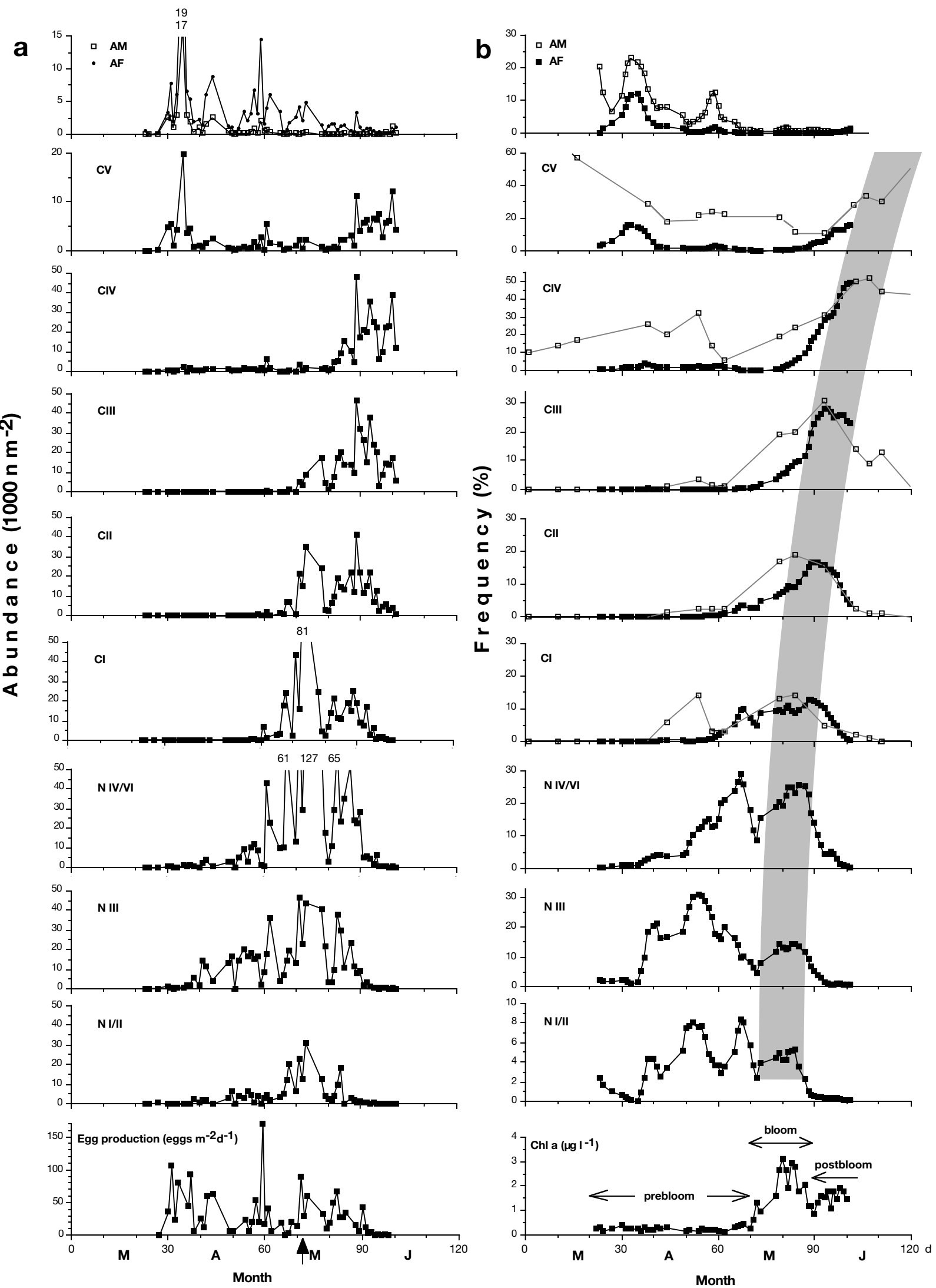

Fig. 2. Absolute (a) and relative (b) stage composition of Calanus finmarchicus at Station M between March and June 1997. Shaded line: suggested cohort development. For comparison, open squares in (b) CI to CV show the stage composition from 1948 (Østvedt 1955, from his Fig. 11) 


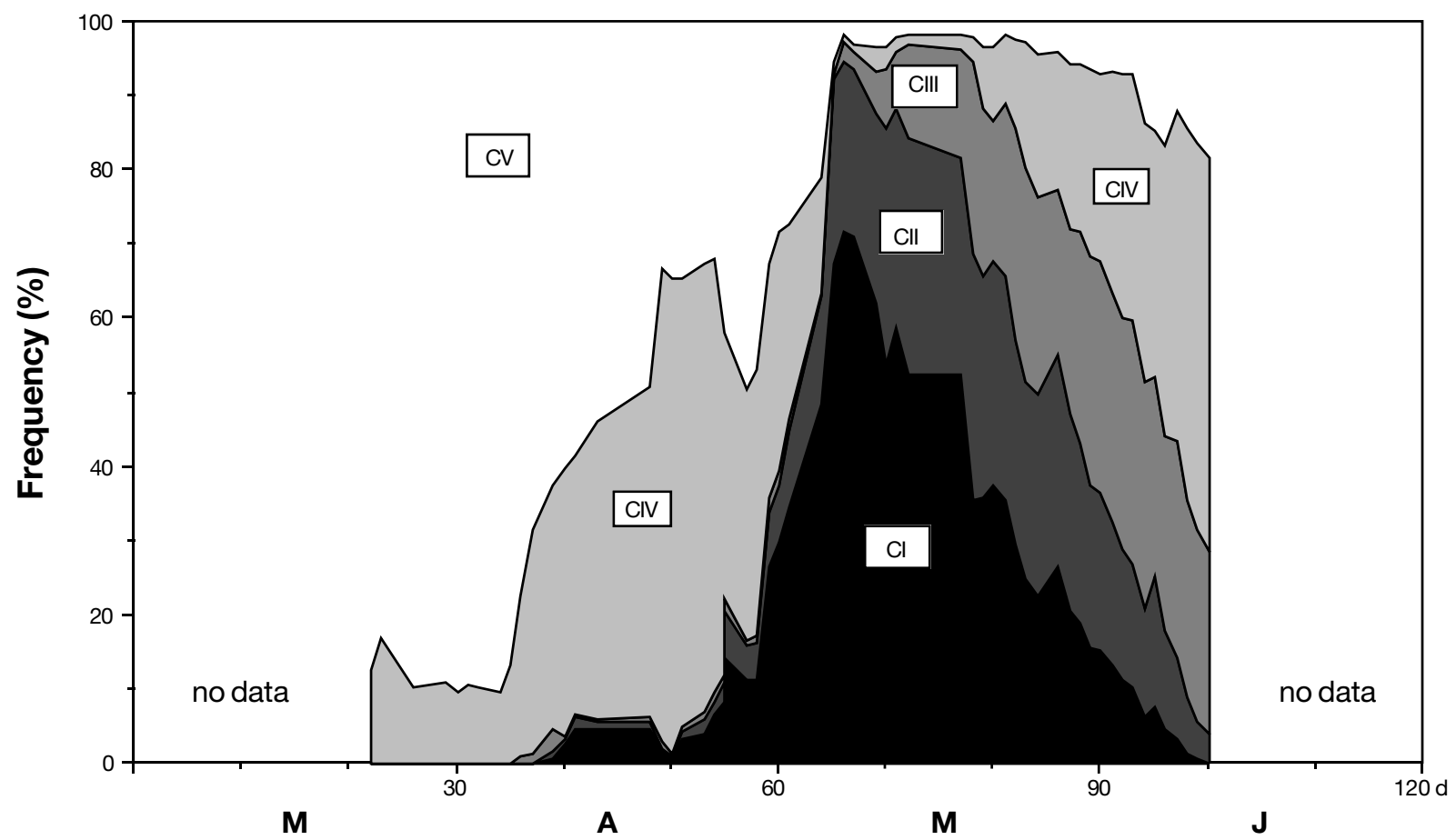

Fig. 3. Cumulative stage distribution of CI to CV of Calanus finmarchicus from Station M. Data were smoothed by a 3-point running average

very low numbers $\left(<100\right.$ ind. $\mathrm{m}^{-2}$; Fig. 2a). NIII was the most frequent of the naupliar groups counted, while the numbers of NI/NII were extremely low, despite continuous and rather steady population egg production rates (Fig. 2a). The portion of nauplii, especially stages NI/NII to NIII, increased strongly from the beginning of April, while NIV to NVI peaked approximately 1 mo later, in mid-May (Fig. 2b). After a steep decrease, also noted in Stages CI to CIII (Fig. 2a), another peak developed at the end of May. Thereafter the naupliar stages disappeared $(<1 \%)$ successively on 28 May (NI/NII), 3 June (NIII) and 7 June (NIV to NVI) despite ongoing egg production. Taking $2 \mathrm{~d}$ for egg development into account, no offspring were found from eggs deposited after 26 May.

Young copepodites were first observed on 10 April, however at very low concentrations. A first increase of CI to CIII was observed at the beginning of May (Fig. 2 ). While there was considerable variability in day-today abundance, the relative stage composition shows a clear successive development within the copepodite stages, with the succession expressed both in the first appearance and maximum (Figs $2 \& 3$ ). The relative stage composition (Fig. 2b) shows that CI and CII had completed most of their development by the end of the study, while CIII had just reached its maximum portion. CIV and CV present in March and April were overwintering stages of the $\mathrm{G}_{0}$ generation. They had maxima in the beginning of April and disappeared thereafter (Fig. 3). New CIV of the $\mathrm{G}_{1}$ generation seemed to be very close to their maximum, and the portion of new $\mathrm{CV}$ was still increasing at the end of the study period. There was no indication yet for an occurrence of $\mathrm{G}_{1}$ adults. The overwintering adults had maxima at the beginning of April and May. Their absolute numbers decreased steadily from a median of $3480 \mathrm{~m}^{-2}$ in April to ca 500 in June. The sex ratio (males:females) decreased from 0.5 in April to $<0.05$ in June.

For comparison of stage development and food concentration, chlorophyll a concentration at the surface and phases of phytoplankton development were added to Fig. 2b. Population egg production rate from Niehoff et al. (1999) is also shown (Fig. 2a). To evaluate the role of the pre-bloom period for population development, Table 4 shows estimates for the presence of the stages of the $\mathrm{G}_{1}$ generation before and after the beginning of the bloom. 10 May was defined as the beginning of the bloom. Accordingly, eggs and nauplii were present much longer during the pre-bloom phase. In contrast, copepodites were present long after 10 May. While CI still spent approximately one-third of its presence in the pre-bloom period, the later copepodite stages hardly showed up before the bloom (CII, CIII) or at the end of the bloom (CIV, CV). Minimum stage durations taken from laboratory rearing at optimal feeding conditions (Campbell et al. in press) and calculated for 
Table 4. Occurrence (days) of eggs and developmental stages of Calanus finmarchicus before and after beginning of the bloom (10 May). Stage durations calculated from Campbell et al. (in press) for $7^{\circ} \mathrm{C}$

\begin{tabular}{|lcccc|}
\hline Stage & Presence & $\begin{array}{r}\text { Before } \\
\text { bloom }\end{array}$ & $\begin{array}{c}\text { After } \\
\text { bloom }\end{array}$ & $\begin{array}{c}\text { Stage } \\
\text { duration }\end{array}$ \\
\hline Eggs & 62 & 41 & 21 & 2 \\
NI/NII & 55 & 36 & 19 & 3.3 \\
NIII & 54 & 35 & 19 & 4.7 \\
NIV/NVI & 54 & 31 & 23 & 7.8 \\
CI & 42 & 13 & 29 & 3.2 \\
CII & 40 & 9 & 31 & 3.8 \\
CIII & 32 & 1 & 31 & 4.8 \\
CIV $\left(\mathrm{G}_{1}\right)$ & 20 & 0 & 20 & 7.3 \\
& & & & \\
\hline
\end{tabular}

$7^{\circ} \mathrm{C}$, i.e. the mean temperature between beginning of April and mid-June at Station M, were added to Table 4. They show that presence, especially of the younger stages, was a manifold of stage duration.

\section{Stage duration}

Stage duration was computed using 2 methods. In Method 1 the steepest increase in MA3 (3 d weighed average, see 'Methods') was used. The times required for development of 3 groups of nauplii and CI to CIV are listed in Table 1.

The median development time method (Method 2, see 'Methods') provided a time series of the proportion of completed molts (Fig. 4); however, difficulties were encountered in calculating stage duration for nauplii due to their extended presence. Thus, only the linear portions of the time series curves were used for stage duration calculations (Fig. 4a, b, Table 5). For NIII and NIV/VI, 2 linear portions were chosen (Fig. 4b), but only the shorter durations are shown in Table 5. Comparison of the different methods shows similar stage durations for the 2 naupliar stages (Table 5), but half the durations for CI to CIII, respectively. For CIV, Method 2, in contrast, gives more than twice the duration as Method 1. This may be due to the fact that CIV still made up only a small portion of the population.

Another, more subjective approach is to follow the peaks of cohorts. The eye-fit trajectory from the latest peaks in the composition of the naupliar stages in Fig. 2b clearly indicates a homogenous cohort developing from NI/NII to CIV. The approximate developmental time for this cohort is $22 \mathrm{~d}$. This is similar to the minimum development time of $24.6 \mathrm{~d}$ calculated for NII (our youngest nauplii, NI and NII, are pooled) until CIV from Campbell et al. (in press) at $7.5^{\circ} \mathrm{C}$, the mean seawater temperature in the upper $100 \mathrm{~m}$ during this growth period.

\section{Productivity and mortality}

The increment summation method estimated daily production to be $51.03 \mathrm{mg} \mathrm{C} \mathrm{m} \mathrm{d}^{-1}$ (Method 1A), $56.52 \mathrm{mg} \mathrm{C} \mathrm{m} \mathrm{C}^{-1}$ (Method 1B) and $56.28 \mathrm{mg}$ $\mathrm{C} \mathrm{m} \mathrm{m}^{-2} \mathrm{~d}^{-1}$ (Method 2) during the $80 \mathrm{~d}$ observation period (Table 1). Correspondingly, productivity amounted to 0.050 and $0.055 \mathrm{~d}^{-1}$, respectively.

Daily mortality rate $Z$ was estimated to be $0.035 \mathrm{~d}^{-1}$ by the single negative exponential model (Fig. 5). Excluding data refering to stages NI/NII and NIII from the regression resulted in an estimate of $Z=0.048 \mathrm{~d}^{-1}$.

Daily carbon-specific egg production rates are presented in Fig. 6. Mean rates were calculated for the pre-bloom $\left(0.02 \mathrm{~d}^{-1}\right)$, bloom $\left(0.066 \mathrm{~d}^{-1}\right)$ and post-bloom $\left(0.0073 \mathrm{~d}^{-1}\right)$ period as defined by Irigoien et al. (1998; see also Fig. 2b). The overall mean of specific egg productivity was $0.031 \mathrm{~d}^{-1}$. Production from SEPR is $30 \mathrm{mg}$ $\mathrm{C} \mathrm{m} \mathrm{m}^{-2} \mathrm{~d}^{-1}$.

For comparison, productivity was computed according to Huntley \& Lopez (1992) from growth rates (their Fig. 2) and from developmental times provided by Campbell et al. (in press), using the mean temperatures in the upper $50 \mathrm{~m}$. The resulting productivity is very similar between these authors, but considerably higher than our field data for SEPR and population development (Fig. 6). Secondary production, as calculated from specific egg production, was $1.84 \mathrm{~g} \mathrm{C} \mathrm{m}^{-2}$; the production of eggs accounted for $0.5 \mathrm{~g}$, or $27 \%$.

\section{DISCUSSION}

\section{Population dynamics}

\section{Stage duration}

Our data show a high degree of mesoscale variability in zooplankton distribution, expressed in considerable changes of biomass and abundance over time. This could reflect methodological problems such as clogging of the nets, or indicate different populations drifting by Station M. The strong variability in abundance and biomass during the very low phytoplankton concentrations of the pre-bloom period (Fig. 1) makes clogging unlikely. The hydrographic data showed the presence of Atlantic water in the upper water layer over the entire study period (Irigoien et al. 1998). One month back-tracking of particles collected at Station M in mid-May using a circulation model driven by the actual meteorological data for our study period shows the most distant origin of particles to be approximately $100 \mathrm{~km}$ to the south, in the Norwegian Basin (D. Slagstad pers. comm.). Furthermore, drifter trajectories (Poulain \& Warn-Varnas 1996) and hydrodynamic 
Table 5. Comparison of stage durations of Calanus finmarchicus from different areas. MTD: median development time method; SI: steepest increase method (see 'Materials and methods' for explanation)

\begin{tabular}{|c|c|c|c|c|c|c|c|c|}
\hline Origin & NIII & NIV/NVI & $\mathrm{CI}$ & CII & CIII & CIV & $T\left({ }^{\circ} \mathrm{C}\right)$ & Reference \\
\hline Norwegian Sea & 13.0 & 9.0 & 6.0 & 7.0 & 9.0 & 12.0 & $6-8$ & Present study, SI \\
\hline Norwegian Sea & 12.6 & 14.6 & 2.6 & 3.4 & 5.9 & 26.3 & $6-8$ & Present study, MTD \\
\hline Gulf of Maine & & & & & 4.0 & $6.6 / 24.8^{\mathrm{a}}$ & 6.0 & Durbin et al. (1995) \\
\hline Nova Scotia & & & & & 5.0 & 5.5 & 7.0 & Runge et al. (1985) \\
\hline Northern Norway & & & 2.4 & 4.6 & 5.8 & 19.0 & 6.0 & Tande (1988) \\
\hline laboratory & 4.7 & 7.8 & 3.2 & 3.8 & 4.8 & 7.3 & 7.0 & Campbell et al. (in press) \\
\hline laboratory & 7.2 & 9.3 & 6.8 & 5.4 & 6.4 & 7.6 & 7.7 & Thompson (1982) \\
\hline laboratory & & & & 4.0 & 5.2 & 5.0 & 8.2 & Corkett et al. (1986) \\
\hline
\end{tabular}

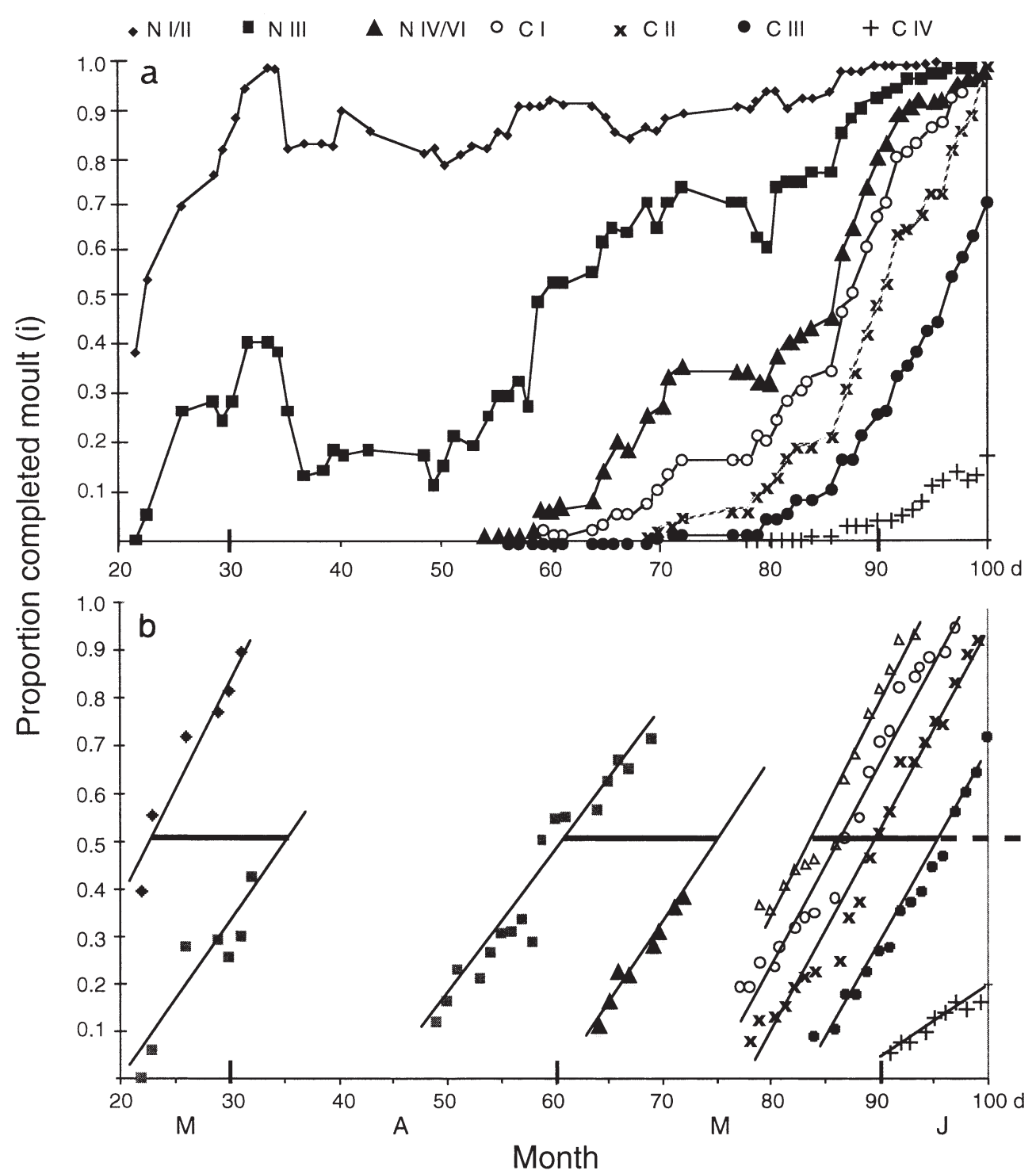

Fig. 4. Calculation of median development time. (a) Time series of the proportion of completed molts filtered with a 4-point running mean. (b) Linear regressions of linear periods in (a). Bars denote the stage durations used in calculations for Table 5 


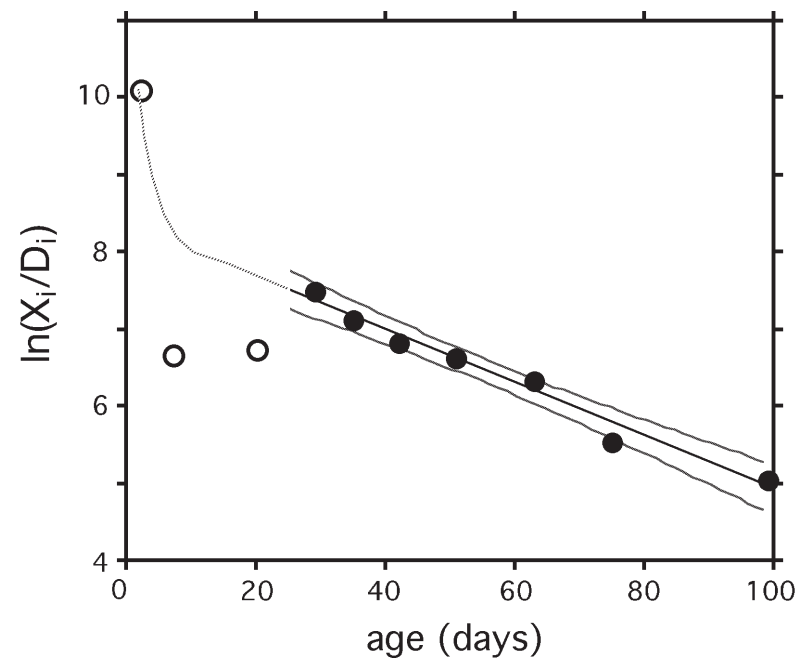

Fig. 5. Mortality of Calanus finmarchicus at Station M estimated by the single negative exponential model. Data are taken from Table 1: $\ln \left(X_{i} / D_{i}\right)=8.289-0.035 \ln$ (cumulative $\left.D_{i}\right) ; \mathrm{r}^{2}=0.614$. With eggs and stages NI/NII and NIII (circles) excluded from the regression (stippled line indicates presumed mortality from eggs to NIII): $\ln \left(X_{i} / D_{i}\right)=9.254-$ $0.048 \ln \left(\right.$ cumulative $\left.D_{i}\right) ; \mathrm{r}^{2}=0.891$

models (Bryant et al. 1998) indicate relatively low current velocities upstream of Station $M$. We thus assume that during the study period only the population of the southeastern Norwegian Basin was collected, which, due to similar environmental conditions, should develop synchronously. This is supported by observations during transects from the shelf to the open Norwegian Sea, south of Station M in April (Niehoff \& Hirche 2000). There was a strong gradient in reproductive variables between shelf and open ocean stations, while between-station variability was low at most open ocean stations. However, food maxima at 2 offshore stations caused significantly higher egg production rates. The significance of such local maxima on basinwide variability of population development certainly deserves more attention.

The variability of abundances made application of population dynamics statistics on stage duration, growth and mortality very difficult. The long duration of the spawning period and, consequently, the extremely long lasting occurrence of some of the developmental stages (Table 4) added further difficulties. The assumptions of constant growth rate and stage duration needed for several models (Aksnes et al. 1997) were impossible to verify from the extended presence of all stages observed here. In contrary, our data suggest a wide range of stage durations, with our numbers probably representing the upper (pre-bloom, Table 5) and lower end (bloom) of the range. The development time of the cohort identified during the bloom is in good agreement with most laboratory observations (Thompson 1982, Table 5 in Tande 1988, Campbell et al. in press). On the other hand, our prebloom values from 2 different approaches (Tables 1 \& 5) are among the lowest ever recorded. These observations clearly indicate food limitation in Calanus finmarchicus, not only for egg production (Niehoff et al. 1999), but also for juvenile growth during most of the period studied. This is decided in contrast to the concept of Huntley \& Lopez (1992) of non-limited growth in the ocean. Similar, Durbin et al. (1995) observed a much longer duration of CIV during a post-bloom $(24.8 \mathrm{~d})$ versus a bloom situation (6.6 d) in the Gulf of

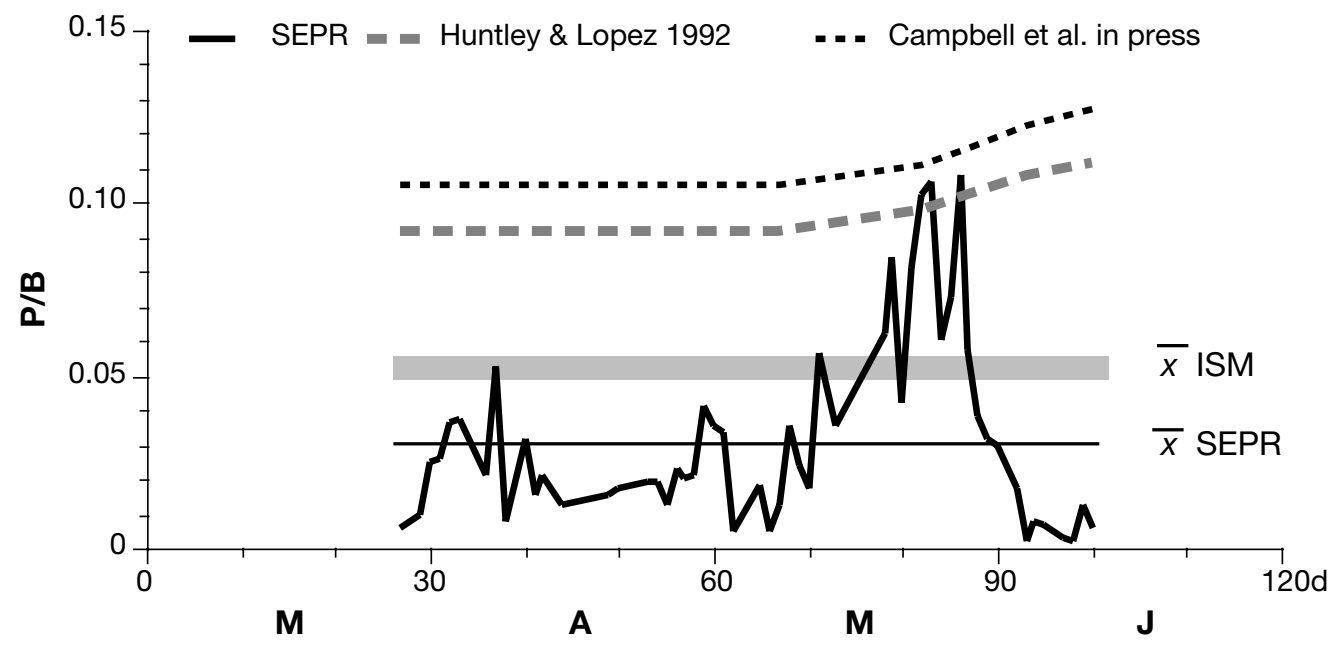

Fig. 6. Comparison of different measures of productivity of Calanus finmarchicus at Station M between March and June 1997. SEPR: specific egg production rate (egg-carbon female-carbon $\left.{ }^{-1}\right), \bar{x}$ SEPR: mean SEPR $i \bar{X}$ ISM: mean by increment summation method 
Maine. Increased stage durations due to unfavorable conditions were reported also from in situ molting experiments in the North Sea by Diel \& Klein Breteler (1986) and Fransz \& Diel (1985). In the laboratory, suboptimal food conditions have recently been shown to increase the development times among nauplii and copepodites considerably (Campbell et al. in press). Measurement of molting rates in other copepods have also shown food limitation (Burkhill \& Kendall 1982, Klein Breteler et al. 1982, Huntley \& Boyd 1984, Runge et al. 1985, Kimmerer \& McKinnon 1987, Berggreen et al. 1988). In contrast, McLaren (1978) and McLaren et al. (1989) concluded, based on cohort analysis, that juveniles in coastal environments completed their development at the same rate as in the laboratory under conditions of unlimited food. Similar arguments were made by Davis (1984).

\section{Productivity and production}

Three different, although not fully independent, numerical methods were applied to estimate productivity and production. Increment summation and mortality rate depend on vertical life tables (sensu Aksnes et al. 1997), whereas the egg production rate method is a rather empirical approach. All methods result in similar estimates of productivity, 0.032 to $0.055 \mathrm{~d}^{-1}$, corresponding to a production of 30 to $56 \mathrm{mg} \mathrm{C} \mathrm{m}^{-2} \mathrm{~d}^{-1}$. The very similar results obtained by Method $1 \mathrm{~A}$ and $1 \mathrm{~B}$ (Table 1) indicate that the population can be considered to be in a steady state, i.e. there is no detectable bias in our data owing to potential vertical migration in or out of the upper $100 \mathrm{~m}$ layer investigated. This seems to validate our results; however, the critical point in increment summation and mortality modeling is stage duration. If we use optimal stage duration data (Campbell et al. in press), which in the field probably only applied to the bloom phase, instead of data from the beginning of the investigation (Table 1), production values increase by 15 to $18 \%$, depending on the method applied. This difference indicates that it is rather unlikely that we overestimated production owing to incorrect determination of stage duration. Including the deep living females found during the beginning of the investigation would alter the production by only a few percentage points, as the total contribution of adults is only ca $6 \%$ (see Table 1 ).

Mean specific egg production was lower by 38 to $45 \%$ as compared to productivity calculated with the increment summation method (Fig. 6). Using a structural female weight of $80 \mu \mathrm{g} \mathrm{C}$ (Carlotti \& Hirche 1997) rather than total weight, as advocated by McLaren \& Leonard (1995), would increase mean specific egg production by only 0.001 . Unfortunately a detailed com- parison of SEPR and juvenile growth was not possible here, as the stage duration estimates did not have sufficient resolution to resolve different food situations. Future studies should therefore apply direct stage duration measurements to correlate both growth measurements. This is especially important during the prebloom phase and during the post-bloom, when egg production was apparently limited (Niehoff et al. 1999) but growth of older stages was not affected.

Comparison of our productivity measurements at Station $\mathrm{M}$ with laboratory experiments under optimal conditions (Huntley \& Lopez 1992, Campbell et al. in press) clearly shows that both unlimited growth and egg production (Fig. 6) took place only during the bloom. For the whole investigation period, the laboratory rates would overestimate productivity by a factor of 2.5 to 4 . Only very few field measurements are available for secondary production in areas dominated by Calanus finmarchicus. On the Fladen Ground $\left(59^{\circ} \mathrm{N}, 1^{\circ} \mathrm{E}\right)$ Fransz \& van Arkel (1980) estimated the production of $C$. finmarchicus during the period examined in the FLEX project, before and after the exponential growth of the population, as $20 \mathrm{mg} \mathrm{C} \mathrm{m}^{-2} \mathrm{~d}^{-1}$. Williams \& Lindley (1980) computed, from stage durations and weight differences during the same project, 490 to $910 \mathrm{mg} \mathrm{C} \mathrm{m}^{-2} \mathrm{~d}^{-1}$ for the exponential growth phase in May, at a very similar temperature regime (6 to $9^{\circ} \mathrm{C}$ ), but Fransz \& Diel (1985) found only an average of $44 \mathrm{mg} \mathrm{C} \mathrm{m}^{-2} \mathrm{~d}^{-1}$ in the same area $7 \mathrm{yr}$ later. In the Skagerrak total production of the copepod populations consisting mainly of small calanoids ranged from 30 to $80 \mathrm{mg} \mathrm{C} \mathrm{m}^{-2} \mathrm{~d}^{-1}$, with an average of $46 \mathrm{mg} \mathrm{C} \mathrm{m}^{-2} \mathrm{~d}^{-1}$. Egg production accounted for $25 \%$ of total production (Peterson et al. 1991), which fits our data (27\%) well.

\section{Mortality}

Data on growth and reproduction of copepods may be obtained more readily than on mortality. It is therefore often difficult to decide whether population growth is controlled by food limitation or by predation. At Station $\mathrm{M}$ an enormous loss was observed between eggs and young naupliar stages (Fig. 5). High mortality rates were also observed in other copepod species, but no data are available for Calanus finmarchicus. For Acartia clausi, Landry (1978) found only ca $20 \%$ survival, and Uye (1982) found ca 7.5\%. Kiørbœ et al. (1988) reported egg mortalities in the order of $99 \%$ in a Swedish fjord. Mortalities around $50 \%$ were observed by Beckman \& Peterson (1986) for A. tonsa, by Daan (1986) for Temora longicornis, and by Ianora et al. (1992) for Centropages typicus.

As eggs, NI and NII are not dependent on food, loss rates are due either to endogenous mortality or preda- 
tion. Direct experimental estimates of endogenous egg mortality in Calanus helgolandicus (Laabir et al. 1995) showed high seasonal variability and an annual mean of $30 \%$, while during the diatom bloom up to $75 \%$ of the eggs were not vital. At Station M, however, diatoms contributed only 8 and $14 \%$ to total phytoplankton during the pre- and post-bloom, respectively, and up to $47 \%$ during the short bloom (Meyer-Harms et al. 1999).

Previous reports attributed in situ copepod mortality during the early life stages mainly to predation (Landry 1978, Ohman 1986, Kiørbœ \& Nielsen 1994, Liang et al. 1994, Peterson \& Kimmerer 1994, Ohman \& Wood 1996). Egg cannibalism by Calanus finmarchicus was frequently observed in the laboratory (Marshall \& Orr 1955). Copepod eggs are a preferred food source for many species of fish larvae (Runge 1988), but also many other types of predator (e.g. Daan 1986). Interestingly, at Station M most of these predators are only found after June (Østvedt 1955).

In contrast to egg mortality, our mean daily mortality estimates ( $Z=3.5$ to $4.8 \%$ ) are lower than those of studies on Calanus finmarchicus from 2 Norwegian fjords. In the Korsfjord, Matthews et al. (1978) estimated a daily mortality rate of $10 \%$ for CIII to CVI. Similarly, in Lindåspollene Aksnes \& Magnesen (1983) observed daily mortality $>10 \%$ when the younger stages were present, and $<1 \%$ when $\mathrm{CV}$ was dominant.

\section{Life history}

Our analysis of the stage distribution of Calanus finmarchicus on Weathership M confirms the importance of the pre-bloom period that was demonstrated in a previous publication on the reproductive physiology of this species (Niehoff et al. 1999). This is in contrast to the classical concept of a close link between the reproduction and growth of $C$. finmarchicus and the spring bloom, which is based on the high food requirements of egg production and juvenile growth (Cushing 1959). Our data show that $C$. finmarchicus does not only spawn half of its eggs long before the bloom, but many of these eggs also develop into feeding naupliar stages and some CI and CII, which seem to accumulate in expectance of the phytoplankton bloom. In contrast to the younger stages, the development of CI to CIII was centered in the bloom phase, and, consequently, the older CIV and CV developed during the post-bloom phase. Thus, the bloom formed a bottleneck for further development of the copepodite stages. It is not clear whether this is due to different feeding mechanisms or food requirements of the young copepodite stages as compared to nauplii and females. In laboratory studies all stages of $C$. finmarchicus grew equally well at concentrations of $0.25 \mu \mathrm{g} \mathrm{C}{ }^{-1}$ (Campbell et al. in press), which is close to our pre-bloom concentrations (Irigoien et al. 1998). The main differences between the pre-bloom and bloom conditions were the larger cell size, the presence of ciliates, no matter how low the concentrations, and the increased portion of diatoms during the bloom (Irigoien et al. 1998, MeyerHarms et al. 1999). Marshall \& Orr (1956) observed no differences in the feeding behavior between younger and older stages of $C$. finmarchicus, although there was a tendency for the setules to be closer in the younger stages.

A remarkably similar population development was observed by Østvedt (1955, his Fig. 11) some 50 yr ago at the same location. In Fig. 2b his stage composition for the year 1948 was added for comparison. He also mentioned considerable numbers of nauplii in April, May and June, from which he concluded the beginning of spawning in the first days of April. Similar to our observations, a first peak in CI was not followed by CII before the bloom, which he related to unfavorable conditions for this part of the brood.

The main benefit of the strategy observed here is probably to spread risk of mortality and to have as many offspring as possible ready to utilize the short window of growth provided by the bloom. The strategy includes an early ascent from diapause, which allows utilization of early blooms in fjords (Tande 1982, Aksnes \& Magnesen 1983, Diel \& Tande 1992), on shelves (Niehoff \& Hirche 2000) and in shelf seas (Williams \& Lindley 1980), as well as along longitudinal gradients in ocean basins such as the Norwegian Sea (Braarud et al. 1958). Early spring spawning helps to cope with predation stress on females due to increased predation by a number of fish species, as suggested by S. Kaartvedt (unpubl.). Predation may have caused the marked decrease in female number, as in laboratory studies they are long-lived and capable of spawning for several months (Hirche 1990, Niehoff \& Hirche unpubl. data). Consequently, an earlier bloom would lead to an increased population egg production rate due to a higher abundance of females. Two week shifts of the timing of the bloom were obtained by Henderson \& Steele (1995) and Radach et al. (1998) from models forced with meteorological data for the North Sea. Even more important for a sustained population development may be a longer period of food conditions, which allows successful transition from nauplii to copepodite stages. To better understand the limiting factors and realistically predict production, more studies are needed on the nutritional requirements of developmental stages at low food concentrations and on the causes of mortality, especially in young stages. 
Acknowledgements. We would like to thank the captain and crew as well as the scientists (R. Head, X. Irigoien, U. Klenke) on RV 'G.O. Sars' for their support. Many thanks are due to the Institute for Marine Research (Bergen, Norway), which kindly provided logistic help. S. Jaklin and E. Mizdalski helped in analyzing the samples. This work was supported by the European Commission through the TASC project, contract MAS3-CT-95-0039. This is publication no. 1767 of the Alfred Wegener Institute for Polar and Marine Research, Bremerhaven.

\section{LITERATURE CITED}

Aksnes DL, Magnesen T (1983) Distribution, development, and production of Calanus finmarchicus (Gunnerus) in Lindåspollene, western Norway, 1979. Sarsia 68:195-208

Aksnes DL, Miller CB, Ohman MD, Wood SN (1997) Estimation techniques used in studies of copepod poplulation dynamics - a review of underlying assumptions. Sarsia 82:279-296

Allen KR (1971) Relation between production and biomass. Can J Fish Aquat Sci 28:1537-1581

Beckman BR, Peterson WT (1986) Egg production by Acartia tonsa in Long Island Sound. J Plankton Res 8:917-925

Berggreen U, Hansen B, Kiørbœ T (1988) Food size spectra, ingestion and growth of the copepod Acartia tonsa during development: implications for determination of copepod production. Mar Biol 99:341-352

Braarud TK, Ringdal G, Nordli J (1958) Seasonal changes in the phytoplankton at various points off the Norwegian West Coast (observations at the permanent oceanographic station, 1945-1946). Fiskeridir Skr Ser Havunders 12/3: $1-77$

Brey T (1999) Growth performance and mortality in aquatic macrobenthic invertebrates. Adv Mar Biol 35:153-243

Bryant AD, Hainbucher D, Heath M (1998) Basin-scale advection and population persistence of Calanus finmarchicus. Fish Oceanogr 7:235-244

Burkhill PH, Kendall TF (1982) Production of the copepod Eurytemora affinis in the Bristol Channel. Mar Ecol Prog Ser 7:21-31

Campbell RG, Wagner MM, Teegarden GJ, Boudreau CA, Durbin EG (in press) Growth and development rates of Calanus finmarchicus reared in the laboratory. Mar Ecol Prog Ser

Carlotti F, Hirche HJ (1997) Growth and egg production of female Calanus finmarchicus: an individual-based physiological model and experimental validation. Mar Ecol Prog Ser 149:91-104

Carlotti F, Radach G (1996) Seasonal dynamics of phytoplankton and Calanus finmarchicus in the North Sea as revealed by a coupled one-dimensional model. Limnol Oceanogr 41:522-539

Carlotti F, Krause M, Radach G (1993) Growth and development of Calanus finmarchicus under temperature influence: experimental results and conceptual model. Limnol Oceanogr 38:1125-1134

Colebrook JM (1982) Continuous plankton records: seasonal variations in the distribution and abundance of plankton in the North Atlantic Ocean and the North Sea. J Plankton Res 41:435-462

Corkett CJ, McLaren IA, Sevigny JM (1986) The rearing of the marine calanoid copepods Calanus finmarchicus (Gunnerus), C. glacialis (Jaschnov) and C. hyperboreus (Krøyer) with comment on the equiproportional rule (Copepoda). In: Schriever G, Schminke HK, Shih CT (eds)
Proc 2nd Int Conf Copepoda. In: Syllogeus 58, Nat Mus Canada, Ottawa, p 539-546

Crisp DJ (1984) Energy flow measurements. In: Holme NA, McIntyre ND (eds) Methods for the study of marine benthos. Blackwell Science, London, p 284-372

Cushing DH (1959) On the nature of production in the sea. Fish Investig Ser II Mar Fish GB Minst Agric Fish Food 22:1-40

Daan R (1986) Food intake and growth of Sarsia tubulosa (Sars 1835), with quantitative estimates of predation on copepod populations. Neth J Sea Res 20:67-74

Daro MH (1980) Field study of the diel feeding of a population of Calanus finmarchicus at the end of a phytoplankton bloom. Meteor Forschergeb Reihe A 22:123-132

Davis CS (1984) Food concentrations on Georges Bank: nonlimiting effect on development and survival of laboratory reared Pseudocalanus sp. and Paracalanus parvus (Copepoda: Calanoida). Mar Biol 82:41-46

Diel S, Klein Breteler WCM (1986) Growth and development of Calanus sp. (Copepoda) during spring phytoplankton succession in the North Sea. Mar Biol 91:85-92

Diel S, Tande KS (1992) Does the spawning of Calanus finmarchicus in high latitudes follow a predictable pattern? Mar Biol 113:21-31

Durbin EG, Gilman SL, Campbell RG, Durbin AG (1995) Abundance, biomass, vertical migration and estimated development rate of the copepod Calanus finmarchicus in the southern Gulf of Maine during late spring. Cont Shelf Res 15:571-591

Fransz HG, Diel S (1985) Secondary production of Calanus finmarchicus (Copepoda: Calanoides) in a transitional system of the Fladen Ground area (northern North Sea) during the spring of 1983. In: Gibbs PE (ed) Proc 19th Eur Mar Biol Symp. Cambridge Univ Press, Cambridge pp123-133

Fransz HG, van Arkel WG (1980) Zooplankton activity during and after the phytoplankton spring bloom at the central station in the FLEX box, northern North Sea, with special reference to the calanoid copepod Calanus finmarchicus (Gunn). Meteor Forschergeb Reihe A 22:113-121

Fromentin JM, Planque B (1996) Calanus and environment in the eastern North Atlantic. II. Role of the North Atlantic oscillation on Calanus finmarchicus and C. helgolandicus. Mar Ecol Prog Ser 134:111-118

Fryd M, Haslund OH, Wohlgemuth O (1991) Development, growth and egg production of the two copepod species Centropages hamatus and Centropages typicus in the laboratory. J Plankton Res 13:683-689

Gaard E (1996) Life cycle, abundance and transport of Calanus finmarchicus in Faroese waters. Ophelia 44: $59-70$

Gamble JC (1978) Copepod grazing during a declining spring phytoplankton bloom in the northern North Sea. Mar Biol 49:303-315

Gislason A, Astthorsson O (1996) Seasonal development of Calanus finmarchicus along an inshore-offshore gradient southwest of Iceland. Ophelia 44:71-84

Henderson EW, Steele JH (1995) Comparing models and observations of shelf plankton. J Plankton Res 17: $1679-1692$

Hirche HJ (1990) Egg production of Calanus finmarchicus at low temperature. Mar Biol 106:53-58

Hirche HJ (1996) The reproductive biology of the marine copepod, Calanus finmarchicus-a review. Ophelia 46: $111-128$

Hirche HJ, Hagen W, Mumm N, Richter C (1994) The Northeast Water Polynya, Greenland Sea. III. Meso- and macro- 
zooplankton distribution and production of dominant herbivorous copepods during summer. Polar Biol 14:491-503

Hopkins TS (1991) The GIN-Sea - a synthesis of its physical oceanography and literature review 1972-1985. Earth-Sci Rev 30:175-318

Huntley M, Boyd C (1984) Food-limited growth of marine zooplankton. Am Nat 124:455-478

Huntley ME, Lopez MDG (1992) Temperature-dependent production of marine copepods: a global synthesis. American Naturalist 140:201-242

Ianora A, Mazzocchi MG, Grottoli R (1992) Seasonal fluctuations in fecundity and hatching success in the planktonic copepod Centropages typicus. J Plankton Res 14: 1483-1494

Irigoien X (2000) Vertical distribution and population structure of Calanus finmarchicus at station India $\left(59^{\circ} \mathrm{N}, 19^{\circ} \mathrm{W}\right)$ during the passage of the great salinity anomaly, 1971-1975. Deep-Sea Res 47:1-26

Irigoien X, Head R, Klenke U, Meyer-Harms B, Harbour D, Niehoff B, Hirche HJ, Harris R (1998) A high frequency time series at Weathership M, Norwegian Sea, during the 1997 spring bloom: feeding of adult female Calanus finmarchicus. Mar Ecol Prog Ser 172:127-137

Kimmerer WJ, McKinnon AD (1987) Growth, mortality, and secondary production of the copepod Acartia tranteri in Westernport Bay, Australia. Limnol Oceanogr 32:14-28

Kiørbœ T, Nielsen TG (1994) Regulation of zooplankton biomass and production in a temperate, coastal ecosystem. 1. Copepods. Limnol Oceanogr 39:493-507

Kiørbœ T, Møhlenberg F, Hamburger K (1985) Bioenergetics of the planktonic copepod Acartia tonsa: relation between feeding, egg production and respiration, and composition of specific dynamic action. Mar Ecol Prog Ser 26:85-97

Kiørbø T, Munk P, Richardson K, Christensen V, Paulsen H (1988) Plankton dynamics and larval herring growth, drift and survival in a frontal area. Mar Ecol Prog Ser 44: 205-219

Klein Breteler WCM, Fransz HG, Gonzalez SR (1982) Growth and development of four calanoid copepod species under experimental and natural conditions. Neth J Sea Res 16: 195-207

Klenke U (1998) Die Reproduktionsbiologie von Calanus finmarchicus (Gunnerus) im Verlauf einer Zeitreihe in der Norwegischen See in Abhängigkeit von biotischen und abiotischen Faktoren. Diploma thesis, Universität Oldenburg

Laabir M, Poulet SA, Ianora A (1995) Measuring egg production in Calanus helgolandicus. J Plankton Res 17: 1134-1137

Landry MR (1978) Population dynamics and production of a planktonic marine copepod, Acartia clausii, in a small temperate lagoon on San Juan Island, Washington. Int Rev Gesamten Hydrobiol 63:77-119

Landry MR (1983) The development of marine calanoid copepods with comments on the isochronal rule. Limnol Oceanogr 28:614-624

Liang D, Uye SI, Onbé T (1994) Production and loss of eggs in the calanoid copepod Centropages abdominalis Sato in Fukuyama Harbor, the Inland Sea of Japan. Bull Plankton Soc Jpn 41:131-142

Marshall SM, Orr AP (1955) The biology of a marine copepod, Calanus finmarchicus Gunnerus. Oliver and Boyd, Edinburgh

Marshall SM, Orr AP (1956) On the biology of Calanus finmarchicus. IX. Feeding and digestion in the young stages. J Mar Biol Assoc UK 35:587-603

Matthews JBL, Hestad L, Bakke JLW (1978) Ecological stud- ies in Korsfjorden, western Norway. The generations and stocks of Calanus hyperboreus and C. finmarchicus in 1971-1974. Oceanol Acta 1:277-284

McLaren IA (1978) Gemeration lengths of some temperate marine copepods: estimation, prediction, and implications. J Fish Res Board Can 35:1330-1342

McLaren IA, Leonard A (1995) Assessing the equivalence of growth and egg production of copepods. ICES J Mar Sci 52:397-408

McLaren IA, Tremblay MJ, Corkett CJ, Roff JC (1989) Copepod production on the Scotian shelf based on life-history analyses and laboratory rearings. Can J Fish Aquat Sci 46: 560-583

Melle W, Skjoldal HR (1987) Zooplankton reproduction in the Barents Sea: vertical distribution of eggs and nauplii of Calanus finmarchicus in relation to spring phytoplankton development. In: Ryland JS, Tyler PA (eds) Reproduction, genetics and distributions of marine organisms. Olsen and Olsen, Fredensborg, p 137-146

Meyer-Harms B, Irigoien X, Head R, Harris R (1999) Selective feeding on natural phytoplankton by Calanus finmarchicus before, during, and after the 1997 spring bloom in the Norwegian Sea. Limnol Oceanogr 44:154-166

Miller CB, Cowles TJ, Wiebe PH, Copley NJ, Grigg H (1991) Phenology in Calanus finmarchicus (Gunnerus); hypotheses about control mechanisms. Mar Ecol Prog Ser 72: 79-91

Niehoff B, Hirche HJ (2000) The reproduction of Calanus finmarchicus in the Norwegian Sea in spring. Sarsia 85: $15-22$

Niehoff B, Klenke U, Hirche HJ, Irigoien X, Head R, Harris R (1999) A high frequency time series at Weathership $M$, Norwegian Sea, during the 1997 spring bloom: the reproductive biology of Calanus finmarchicus. Mar Ecol Prog Ser 176:81-91

Ohman MD (1986) Predator-limited population growth of the copepod Pseudocalanus sp. J Plankton Res 8:673-713

Ohman MD, Runge JA (1994) Sustained fecundity when phytoplankton resources are in short supply: omnivory by Calanus finmarchicus in the Gulf of St. Lawrence. Limnol Oceanogr 39:21-36

Ohman MD, Wood SN (1996) Mortality estimation for planktonic copepods: Pseudocalanus newmani in a temperate fjord. Limnol Oceanogr 41:126-135

Østvedt OJ (1955) Zooplankton investigations from weathership 'M' in the Norwegian Sea, 1948-49. Hvalrådets Skr 40:1-93

Peterson WT, Kimmerer (1994) Processes controlling recruitment of the marine calanoid copepod, Temora longicornis in Long Island Sound: egg production, egg mortality, and cohort survival rates. Limnol Oceanogr 39:1594-1605

Peterson WT, Tiselius P, Kiørbœ T (1991) Copepod egg production, moulting and growth rates, and secondary production, in the Skagerrak in August 1988. J Plankton Res 13:131-154

Planque B, Fromentin JM (1996) Calanus and environment in the eastern North Atlantic. I. Spatial and temporal patterns of Calanus finmarchicus and C. helgolandicus. Mar Ecol Prog Ser 134:101-109

Plourde S, Runge JA (1993) Reproduction of the planktonic copepod Calanus finmarchicus in the lower St. Lawrence estuary: relation to the cycle of phytoplankton production and evidence for a Calanus pump. Mar Ecol Prog Ser 102: 217-227

Poulain P-M, Warn-Varnas A (1996) Near surface circulation of the nordic seas as measured by Lagrangian drifters. J Geophys Res 101:18237-18258 
Radach G, Carlotti F, Spangenberg A (1998) Annual weather variability and its influence on the population dynamics of Calanus finmarchicus. Fish Oceanogr 7:272-281

Rigler FH, Downing JA (1984) The calculation of secondary productivity. In: Downing JA, Rigler FH (eds) A manual on methods for the assessment of secondary productivity in fresh waters. Blackwell Science, Oxford, p 19-58

Runge JA (1985) Egg production rates of Calanus finmarchicus in the sea of Nova Scotia. Arch Hydrobiol Suppl 21: $33-40$

Runge JA (1988) Should we expect a relationship between primary production and fisheries? The role of copepod dynamics as a filter of trophic variability. Hydrobiologia 167/168:61-71

Runge JA, McLaren IA, Corkett CJ, Bohrer RN, Koslow JA (1985) Molting rates and cohort development of Calanus finmarchicus and C. glacialis in the sea off southwest Nova Scotia. Mar Biol 86:241-246

Slagstad D, Tande K (1996) The importance of seasonal vertical migration in across shelf transport of Calanus finmarchicus. Ophelia 44:189-205

Steele JH (1998) From carbon flux to regime shift. Fish Oceanogr 7:176-181

Editorial responsibility: Otto Kinne (Editor),

Oldendorf/Luhe, Germany
Tande KS (1982) Ecological investigations on the zooplankton community of Balsfjorden, northern Norway: generation cycles, and variations in body weight and body content of carbon and nitrogen related to overwintering and reproduction in the copepod Calanus finmarchicus. J Exp Mar Biol Ecol 62:129-142

Tande KS (1988) Aspects of developmental and mortality rates in Calanus finmarchicus related to equiproportional development. Mar Ecol Prog Ser 44:51-58

Thompson BM (1982) Growth and development of Pseudocalanus elongatus and Calanus sp. in the laboratory. J Mar Biol Assoc UK 62:359-372

Uye SI (1982) Population dynamics and production of Acartia clausi Giesbrecht (Copepoda: Calanoida) in inlet waters. J Exp Mar Biol Ecol 57:55-83

Williams R (1988) Spatial heterogeneity and niche differentiation in oceanic zooplankton. In: Boxshall GA, Schminke HK (eds) Biology of copepods. Hydrobiologia 167/168: 151-159

Williams R, Lindley JA (1980) Plankton of the Fladen Ground during FLEX 76. III. Vertical distribution, population dynamics and production of Calanus finmarchicus (Crustacea: Copepoda). Mar Biol 60:47-56

Submitted: May 25, 2000; Accepted: February 27, 2001

Proofs received from author(s): August 22, 2001 